\title{
The Analysis of Ecological Awareness of Students of SMK Migas Cepu
}

\author{
Fitriah Hanim $^{1}$, Djono ${ }^{2}$, Susanto ${ }^{3}$ \\ ${ }^{1,2,3}$ Postgraduate Program in Historical Education, Faculty of Teacher Training and Education, Universitas \\ Sebelas Maret, Indonesia \\ fitriahhanim44@student.uns.ac.id,mailto:djono@staff.uns.ac.id,mailto:susantofibuns@staff.uns.ac.id
}

\begin{abstract}
The history of petroleum in Cepu, which has not been explored and taught to students, makes students' knowledge of the environment low. This study aims to analyze the extent to which students' knowledge of the environment and ecological awareness possessed by students of SMK Migas Cepu. By using the case study method, the principles of ecological literacy outlined by the researcher in the form of a questionnaire become the basis for knowing students' understanding and awareness of their environment. To provide students with an understanding of the negative impact of oil refineries in relation to fostering attitudes and knowledge of ecology, researchers provide learning the history of petroleum through the guided inquiry method with the aim of helping students to bring up character values, namely a caring attitude towards the environment. The resultthat the significance of $0.000<0.05$, it can be concluded that $\mathrm{HO}$ is rejected and $\mathrm{HI}$ is accepted that There is a mean difference between the control and experimental classes. So that dapat disimreport that the questionnaire developed was effective in increasing students' ecological awareness.
\end{abstract}

Keywords petroleum history; guided inquiry; students' ecological awareness

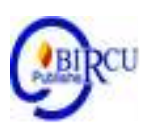

\section{Introduction}

Preserving ecology is very important for natural and human life. But in reality human ecological awareness is still very low. Lualhati, Catibog, Holgado, \& Liwanag (2018) define ecological awareness as a way of thinking about the world in terms of natural and human interdependent systems, including consideration of the consequences of human actions and interactions in a natural context. Furthermore, to make people ecologically literate, there are three components, namely cognitive (knowledge), affective (caring), and behavior (practical competence).

According to The responsibility for cultivating ecological awareness is carried out by making every student want to be friends with nature, which separates waste, conserves water and energy, and follows the idea of a balanced development throughout their life. According to ecological awareness can be grown in schools by implementing the Adiwiyata program, with the aim to create schools that care about the environment and are able to participate in and implement efforts to preserve a sustainable environment. The Adiwiyata program helps introduce students to environmental education.

Ecological awareness at SMK Migas Cepu is low. This can be seen from the habits of students who really like littering, such as under desks, in the back corner of the classroom, the toilet has changed its function to a place to dispose of tissue and others. Ideally, in 
accordance with one of the school's vision and mission, which is to form human resources with environmental culture, students of SMK Migas Cepu have a good ecological awareness.

Moreover, the environmental impact in Cepu from Cepu refinery waste comes from mining activities carried out by PT. Pertamina EP Java Region Cepu Field from the Kawengan, Ledok and Nglobo fields which only got attention in 1985. The existence of oil in Cepu began by 1886 Andrian Stoop. Andrian Stoop started the company since 1887 which was namedDe Dordtsche Petroleum Maatschappij (DPM). Then in 1911 the dordtsche company was taken over by Bataafsche Petroleum Maatschappij (BPM) or Shell from the Dutch royal skin and made the group's marketing company throughout the Dutch East Indies.. 1962 Shell was nationalized, which actually experienced a decrease in production due to a shortage of experts. In 1966, after going through negotiations on the Cepu oil mine, which experienced a decline in production, it was agreed to be handed over to Lemigas to become a center for education and training for oil and gas. After that the Oil and Gas Academy (Akamigas) was established in 1966. To organize the management of Akamigas in Cepu, the Oil and Gas Field Education and Training Center (Pusdiklat Migas) was formed. The existing oil field is then used as a means of educational demonstration.. In addition to being established Akamigas, SMK Migas was also established starting in 1961 and only had an oil department in 2005.

The establishment of the Cepu oil refinery in 1928, there was no obligation regarding an AMDAL (Environmental Impact Analysis), so that attention to environmental management was not so serious. Environmental management, especially waste management, only received serious attention starting in 1985 before the enactment of Government Regulation no. 29 of 1986 regarding AMDAL (Environmental Impact Analysis). The waste management is carried out by completing the waste oil treatment facilities and facilities using the oil catcher method. Based on PP No. 18 of 1999 jo. PP no. 85 of 1999 concerning the management of B3 waste (Hazardous and Toxic Materials), oil spills in the refinery area are included in the category of B3 waste code D 221, because their nature and concentration can endanger human health and the environment.tif, poisonous, infectious, corrosive and is carcinogenic (causes cancer).

The ecological conditions in Cepu are very dangerous for the life around them, students of SMK Migas Cepu are very important to get knowledge about the history of oil because it is closely related to their vocational skills which can be used as a provision for the future, regardless of the history of petroleum has positive and negative impacts, especially with regard to issues. environment that has never been taught and explored and low awareness of ecology in schools is very helpful to build students' knowledge of the importance of protecting the environment. As with the opinion of Fattah (2020) that vocational schools in the practical dimensions of historical learning must be included in the vision of links and facts where learning in schools and the needs of workforce in the industrial world are appropriate. Learning local history is the study of the life of a particular community or community in the dynamic development of human life (Rosmiati, 2020).

This study aims to analyze the ecological awareness of the students of SMK Migas Cepu. Analysis of ecological awareness is important because of the widespread damage to the environment due to human interests and the uncontrollable development of science and technology, as well as students' low knowledge of the surrounding environment. With this research, is expected to build the character of students who are aware of their environment. reverence for nature and gross abuse of nature in order to honor nature Culture and the ecological belief that human beings and culture have a harmonious connection (Basirizadeh, 2020). 


\section{Review of Literatures}

\subsection{Ecological Awareness}

Refers to theory (Lualhati, Catibog, Holgado, \& Liwanag, 2018b) about ecological consciousness which depends on how people think about the world. For that then, Bruyere (2008) to make people ecologically literate, there are three components, namely cognitive (knowledge), affective (caring), and behavior (practical competence). Caring measures the level of a person's affection for environmental protection and social justice. Caring people, in this context, feel a desire and are responsible for reducing their personal and communal impacts on the ecological system. This section reflects a person's thoughts, not actions. Knowledge represents an understanding of ecological principles and human interactions with their natural and artificial environments.

Through these experiences, it is possible that such people will be able to better connect the three areas of ecological literacy. For example, giving students the opportunity to work on a farm and eat the food they harvest gives students a space to learn about agriculture; connect students to work because they are in the field, not at the table; and give students the opportunity to take action and emulate that action. Programs that combine care, knowledge, and action have the potential to greatly enhance students' ecological literacy and the ecological literacy of those around them.(Mcginn, 2014)

In addition, according to Cherrett, as cited by Mcginn (2014), one needs to be aware of the environment, as this is the basis and starting point of literacy. Today, knowledge is no longer limited to the extent of memorizing concepts, but raising awareness is a prerequisite for successful learning. Ecologically conscious people will have an understanding of important ecological concepts such as ecosystem succession, energy flow, cycling of materials, ecological adaptation, food webs, carrying capacity, and species diversity.

Ecological literacy is also supported by several ecological principles to create a sustainable society. According to A Sonny Keraf (2013) in Capra, there are five principles of ecological literacy or ecoliteracy, namely as follows:(Keraf, 2013)

1. The principle of independence that is between nature and humans has an interrelated relationship. Life in nature depends on other life. In other words, the existence, wholeness, life and development of each member determine the existence, wholeness, life and development of each other member, and on the other hand, also determine the existence, integrity, life and development of the entire ecological community. But on the contrary, the existence, wholeness, life and development of the ecological community all determine the existence, integrity, life and development of each member.

2. The principle of recycling, which is a life process like the food chain, in other words, the remaining products of the life process as waste are not wasted, but all of them are reabsorbed as energy and food for life processes in a non-linear cyclic relationship.

3. The Principle of Partnership, namely in life on earth is interrelated, mutually supporting, mutually supporting, participate actively, voluntarily to live and support each other and cooperate.

4. The principle of flexibility (easy to adapt), namely the human community must be open to change and without being carried away by it. The human community must develop by maintaining its identity and identity while still adapting to change and absorbing changes and progress that occur around it.

5. The principle of diversity is that humans are diverse in ethnicity, culture, language. 
So that human principles which are not like the five principles above will damage our ecology. To restore the ecological damage that is around us, we must use these five principles for a sustainable life for humans and nature.

According to (Suwandi \& Yunus, 2016) The components covered by ecological intelligence include:

1. Identify the components of the ecosystem, both abiotic and biotic

2. Understand the functions and uses of ecosystem components, both abiotoc and biotic

3. Understand natural and environmental management systems, both abiotic and biotic

4. Understand environmental values, which include local wisdom values, religious values, and normative values

5. Shows concern over environmental damage or environmental pollution, both abiotic and biotic

6. Adapt behavior to the environment, both abiotok and biotic

7. Solve problems arising from environmental impacts (abiotic and biotic), both individually and collectively

8. Manage / conserve natural resources (abiotic and biotic), both individually and collectively

9. Make positive use of the environment (abiotic and biotic), both individually and collectively

Supporting this, the center for ecoliteracy (Center for Ecoliteracy) is available in https $/ /$ www.ecoliteracy.org/publications/fritjophas developed a set of "core competencies" to help young people develop and live in sustainable societies. This competency is related to knowledge (learning to know), attitudes (learning to be), action (learning to do) and relationships with humans and nature (learning to live together). These competencies include:

Table 1. Core Competencies of Ecological Awareness

\begin{tabular}{|c|c|}
\hline $\begin{array}{l}\text { The core competencies of } \\
\text { the Center for Ecoliteracy }\end{array}$ & $\begin{array}{l}\text { The sub-competencies of the Center for Ecoliteracy's } \\
\text { core competencies }\end{array}$ \\
\hline Knowledge aspect & $\begin{array}{l}\text { - Understand environmental issues and } \\
\text { problems from the perspective of ecological } \\
\text { balance and sustainability. } \\
\text { - Understand the principles of ecology } \\
\text { - Think critically, solve problems creatively } \\
\text { and apply knowledge to new situations } \\
\text { - Assess the impact or effect of human action } \\
\text { and apply technology to the environment } \\
\text { - Taking into account the long-term } \\
\text { consequences of making a decision and } \\
\text { taking into account the long-term } \\
\text { consequences of a decision }\end{array}$ \\
\hline Attitude aspect & $\begin{array}{l}\text { - Give attention, empathy, and respect to others } \\
\text { and other living things } \\
\text { - Respect for differences in background, } \\
\text { motivation, intention to interact in } \\
\text { accordance with the perspective of mutual }\end{array}$ \\
\hline
\end{tabular}




\begin{tabular}{|l|l|}
\hline & $\begin{array}{l}\text { respect for the value of cooperation } \\
\text { Committed to equality, fairness, inclusiveness } \\
\text { and respect for all people }\end{array}$ \\
\hline Aspects of skills & $\begin{array}{l}\text { Create and use the tools, objects, and } \\
\text { producers needed by a sustainable society }\end{array}$ \\
- $\begin{array}{l}\text { Put into practice practical action and be } \\
\text { effective in applying a caring understanding } \\
\text { of ecological balance } \\
\text { Assess and utilize energy and resources } \\
\text { according to their use }\end{array}$ \\
\hline
\end{tabular}

To find out how far the principle of ecological literacy has succeeded, it is not only tested in the fields of politics, industry but also in education. In the world of education, it is very important to provide students with an understanding of the environmental conditions around them, because it will help change wrong ecological principles with correct ones. One school that can be used as a reference in this case is SMK Migas Cepu. Students at SMK Migas Cepu have low ecological awareness. Therefore, referring to the principles of ecology, the core competencies of ecology can be tested with the following indicators of research success and questionnaires:

Table 2. Indicators of Success in Ecological Awareness Research

\begin{tabular}{|c|c|c|}
\hline $\begin{array}{l}\text { The core } \\
\text { competencies } \\
\text { of the Center } \\
\text { for Ecoliteracy }\end{array}$ & $\begin{array}{l}\text { The sub-competencies of the } \\
\text { Center for Ecoliteracy's core } \\
\text { competencies }\end{array}$ & $\begin{array}{l}\text { Research } \\
\text { Indicators }\end{array}$ \\
\hline $\begin{array}{l}\text { Knowledge } \\
\text { aspect }\end{array}$ & $\begin{array}{l}\text { - Understand environmental } \\
\text { issues and problems from } \\
\text { the perspective of } \\
\text { ecological balance and } \\
\text { sustainability. } \\
\text { - Understand the principles of } \\
\text { ecology critically, solve } \\
\text { - Think ank } \\
\text { problems creatively and } \\
\text { apply knowledge to new } \\
\text { situations } \\
\text { - Assess the impact or effect } \\
\text { of human action and apply } \\
\text { technology to } \\
\text { environment the } \\
\text { Taking into account the } \\
\text { long-term consequences of } \\
\text { making a decision and } \\
\text { taking into account the } \\
\text { long-term consequences of } \\
\text { a decision }\end{array}$ & 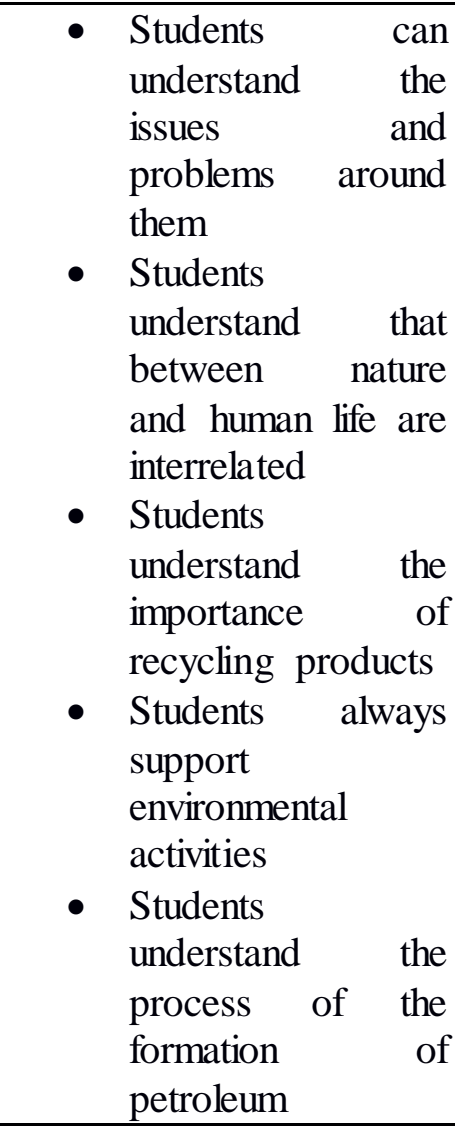 \\
\hline
\end{tabular}




\begin{tabular}{|c|c|c|}
\hline & & 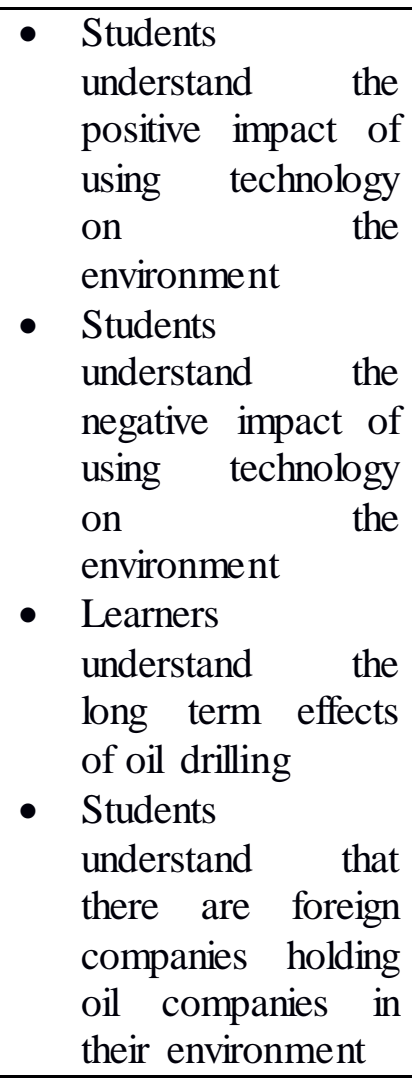 \\
\hline Attitude aspect & $\begin{array}{l}\text { - Give attention, empathy, } \\
\text { and respect to others and } \\
\text { other living things } \\
\text { - Respect for differences in } \\
\text { background, motivation, } \\
\text { intention to interact in } \\
\text { accordance with the } \\
\text { perspective of mutual } \\
\text { respect for the value of } \\
\text { cooperation } \\
\text { - Committed to equality, } \\
\text { fairness, inclusiveness and } \\
\text { respect for all people }\end{array}$ & 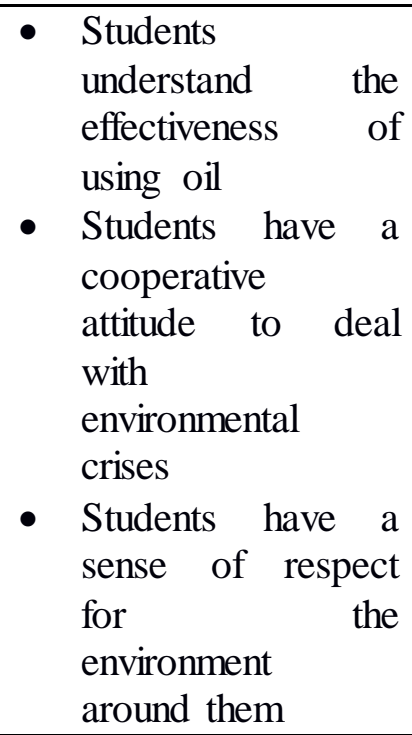 \\
\hline $\begin{array}{l}\text { Aspects } \\
\text { skills }\end{array}$ & 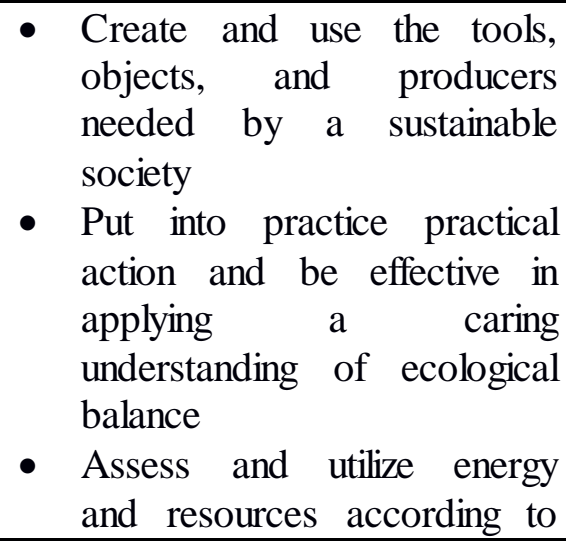 & 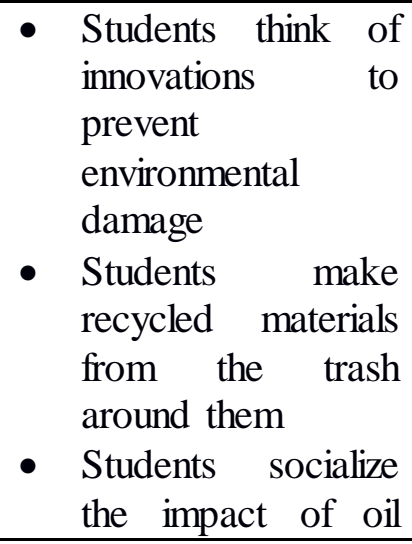 \\
\hline
\end{tabular}




\begin{tabular}{|l|l|l|}
\hline their use & $\begin{array}{l}\text { drilling to friends } \\
\text { in other } \\
\text { departments }\end{array}$ \\
& $\begin{array}{l}\text { Students plant } \\
\text { trees to protect }\end{array}$ \\
& their environment \\
& Students bury leaf \\
& and animal litter \\
& around them \\
\hline
\end{tabular}

\section{Research Methods}

\subsection{Research Design}

This study uses a case study method to formulate an analysis of the ecological awareness of the students of SMK Migas Cepu. (Yin, 2017)formulating 6 steps in conducting a case study, namely: (1) Plan (early knowing what and when to use a case study), (2) Design (identifying the case studied and forming the case study to make sense), (3) Prepare (prepare, collect what cases are needed before starting case study data), (4) Collect (collect basic case study evidence from at least 6 sources in the form of: documentation, archival notes, interviews, direct observation, participant observation, physical artifacts) (5) Analyze ( analyze case studies), (6) share (report and compile the results of the case studies). The results and findings of this paper are the results of the ecological awareness questionnaire and the analysis of the results of the questionnaire is why the ecological awareness of the students of SMK Migas Cepu is low.

\subsection{Research Respondents}

Research respondents include students who have almost the same characteristics and abilities. In this case, the students of class $\mathrm{X}$ SMK Migas Cepu majoring in Oil and Petrochemical Processing (T.PMP) class A, amounting to (27) and B (27).

\subsection{Research Instruments}

The research instrument used students' ecological awareness questionnaires. This questionnaire uses a Likert scale with 4 answer options, namely:

Never: 1

Rarely: 2

Often: 3

Always: 4

Table 3. Students' Ecological Awareness Questionnaires

\begin{tabular}{|l|l|l|l|l|l|}
\hline No. & \multicolumn{1}{|c|}{ Question } & \multicolumn{4}{c|}{ Answer } \\
\cline { 3 - 6 } & & 1 & 2 & 3 & 4 \\
\hline 1. & $\begin{array}{l}\text { I understand the dangers of wastewater pollution to } \\
\text { human health }\end{array}$ & & & & \\
\hline 2. & I studied the process of the formation of petroleum & & & & \\
\hline 3. & $\begin{array}{l}\text { I learned that oil processing will be faster using a } \\
\text { machine }\end{array}$ & & & & \\
\hline 4. & I understand the negative impacts of oil drilling & & & & \\
\hline 5. & I understand that if a pipe leak occurs, it will kill & & & & \\
\hline
\end{tabular}




\begin{tabular}{|l|l|l|l|l|l|}
\hline & the biota in Solo & & & & \\
\hline 6. & $\begin{array}{l}\text { I understand the danger that an oil spill will block } \\
\text { sunlight from entering the water }\end{array}$ & & & & \\
\hline 7. & $\begin{array}{l}\text { I understand that exploitation will lead to global } \\
\text { warming }\end{array}$ & & & & \\
\hline 8. & I understand exploitation leads to smog & & & & \\
\hline 9. & I am innovating how to use petroleum effectively & & & & \\
\hline 10. & $\begin{array}{l}\text { My friends and I work together to deal with the } \\
\text { environmental crisis }\end{array}$ & & & \\
\hline 11. & I use plastic waste to make crafts & & & & \\
\hline 12. & I water the flowers in front of my class & & & & \\
\hline 13. & I throw the trash in its place & & & & \\
\hline 14. & I took my friend's trash and put it in the trash & & & \\
\hline 15. & $\begin{array}{l}\text { I think of innovations to reduce environmental } \\
\text { damage }\end{array}$ & & & & \\
\hline 16. & $\begin{array}{l}\text { I follow school rules not to use plastic wrap on } \\
\text { food }\end{array}$ & & & & \\
\hline 17. & $\begin{array}{l}\text { I socialize the impact of drilling to my friends in } \\
\text { other departments }\end{array}$ & & & & \\
\hline 18. & I participated in planting 1000 trees & & & & \\
\hline 19. & I help bury the plants that have been cut down & & & & \\
\hline 20. & I help bury dead animals / bones around me & & & & \\
\hline
\end{tabular}

\section{Discussion}

\subsection{Petroleum History Leaming with Guided Inquiry}

Learning activities using hendout thatconducted in two meetings. The first meeting served as an introduction through a zoom meeting and giving a pretest both in the form of an ecological awareness questionnaire. And the second meeting was delivering material through zoom meetings through power points and hendouts and giving posttests. The learning process is carried out using the Learning Implementation Plan (RPP) which has been discussed with the Indonesian history subject teacher. Giving pretest and posttest questionnaires through word files sent via WA.

The following are the steps of the learning process using the guided inquiry learning model:

Table 4. Learning Steps

\begin{tabular}{|c|c|c|}
\hline Learning Steps & Details of activities & $\begin{array}{c}\text { Time } \\
\text { Allocation }\end{array}$ \\
\hline preliminary & $\begin{aligned} & \begin{array}{l}\text { Educators say greetings, } \\
\text { make presence, prepare } \\
\text { learning devices. }\end{array} \\
& \text { Educators do apperception to } \\
& \text { motivate students about the } \text { importance of learning the } \\
& \text { material to be delivered } \\
&>\end{aligned}$ & 5 minutes \\
\hline
\end{tabular}




\begin{tabular}{|c|c|c|}
\hline Core activities & $\begin{aligned} &> \text { Educators explain the } \\
& \text { historical material of Dutch } \\
& \text { oil exploration in Cepu } \\
& \text { through power points and } \\
& \text { hendouts. } \\
&>\text { Each student identifies the } \\
& \text { problem of mining activities } \\
&> \text { Each student follows a } \\
& \text { hypothetical step } \\
&> \text { Each student collects data } \\
& \text { from teaching materials } \\
&> \text { Each student tests the } \\
& \text { hypothesis that is made } \\
&> \text { Each student interprets the } \\
& \text { data obtained } \\
&> \text { Each student concludes the } \\
& \text { results by writing them in the } \\
& \text { assignment book }\end{aligned}$ & 30 minutes \\
\hline Closing & $\begin{array}{l}>\text { Educators provide } \\
\text { conclusions and benefits of } \\
\text { today's learning. } \\
>\text { Educators ask students to fill } \\
\text { out an ecological awareness } \\
\text { questionnaire } \\
>\text { The educator ends the } \\
\text { meeting and says hello. }\end{array}$ & 10 minutes \\
\hline
\end{tabular}

\subsection{Ecological Awareness in SMK Migas Cepu Students}

To write down the results of the research, the researcher adopted the research design of Robert K. Yin, there were 6 steps, namely: Plan, Design, Prepare, Collect, Analyze and Share, which will be explained in more detail below:

Table 5. Research Steps

\begin{tabular}{|l|l|l|}
\hline No. & Steps & \multicolumn{1}{|c|}{ Information } \\
\hline 1. & Plan & Planning research on ecological awareness. \\
\hline 2. & Design & $\begin{array}{l}\text { Identifying the ecological awareness of students of } \\
\text { SMK Migas Cepu. }\end{array}$ \\
\hline 3. & Prepare & $\begin{array}{l}\text { Prepare and collect cases in the form of (students' } \\
\text { ecological awareness knowledge of the } \\
\text { environmental impact of students). }\end{array}$ \\
\hline 4. & Collect & $\begin{array}{l}\text { Collecting participant observation evidence in the } \\
\text { form of an ecological awareness questionnaire. }\end{array}$ \\
\hline 5. & Analyze & $\begin{array}{l}\text { Analyze students ecological awareness obtained } \\
\text { from the questionnaire. }\end{array}$ \\
\hline 6. & Share & $\begin{array}{l}\text { Writing down the results of the ecological } \\
\text { awareness analysis of the students of SMK Migas } \\
\text { Cepu }\end{array}$ \\
\hline
\end{tabular}


Based on the six steps above, the analysis of ecological awareness in SMK Migas Cepu students using an ecological awareness questionnaire in the form of pretest and posttest data in class X PMP A and X PMP B are as follows:

Table 6. Pretest Results of Ecological Awareness Attitudes of Experiment and Control Classes

\begin{tabular}{|c|l|c|l|c|}
\hline \multirow{2}{*}{ No } & \multicolumn{2}{|c|}{ Control Class } & \multicolumn{2}{c|}{ Experiment Class } \\
\cline { 2 - 5 } & \multicolumn{1}{|c|}{ Name } & Pretest & \multicolumn{1}{c|}{ Name } & Pretest \\
\hline 1 & Abdul Wafi & 52 & Ade Maula Yahya & 57 \\
\hline 2 & Afif Aminudin & 69 & Ardian Farid & 53 \\
\hline 3 & Alifah Firdhausyah & 44 & Ariel Dwi Ramadhani & 57 \\
\hline 4 & Alziqhra January & 69 & Aulia Mutiara Arseti & 44 \\
\hline 5 & Amanda Putri Rizqiya & 41 & Choirun Nisa & 56 \\
\hline 6 & Andhika Cahya & 50 & Peaceful Kayla Rezka & 71 \\
\hline 7 & Andika Eka Pratama & 52 & Dinda Ayu Trihapsari & 41 \\
\hline 8 & Chelsea Widya Santoso & 50 & Hammam Sholihin & 53 \\
\hline 9 & Dailly Drasta House & 41 & Ilham Afbel Karaka & 44 \\
\hline 10 & Dannel Susriatmanto & 46 & Java Bagus Maylana & 46 \\
\hline 11 & Davit Mustika & 53 & Julinka Nareswari & 58 \\
\hline 12 & Devinta Aprillia & 38 & M. Zaidan Dzaki Kansa & 70 \\
\hline 13 & Elsa Eliyanti Hutabarat & 70 & Margareta Videllia Chika & 60 \\
\hline 14 & Fajri Andinikhlas & 63 & Monika Ulim & 45 \\
\hline 15 & Holizah & 60 & Muhammad Ilham Mufaddil & 55 \\
\hline 16 & Izaki Surya Abdullah & 55 & Muhammad Rafi & 64 \\
\hline 17 & Jaka Afriza Nurchosim & 55 & Niken Zhulia Ayu Astutik & 58 \\
\hline 18 & Kayana Amoretta & 53 & Pritia Dwi Yulianti & 55 \\
\hline 19 & Luthfiah Adelya & 55 & Purnomo Hadi Saputro & 50 \\
\hline 20 & Moh. Anwar Rudin & 40 & Radiq Bima Alditya & 57 \\
\hline 21 & Muhammad Ilham & 59 & Rahadian Rizqy Irawan & 50 \\
\hline 22 & Muhammad Rendy & 38 & Renovaldy Arya & 70 \\
\hline 23 & Muhammad Ridlo & 69 & Rifaul Ihsan & 40 \\
\hline 24 & Naufal Hisyam & 53 & Selvia Yulira Pratama & 55 \\
\hline 25 & Patricia Aurha De Priza & 44 & Sophie Nayla Fattima & 56 \\
\hline 26 & Sandrina Widyatma & 68 & Yuniar Andini Ainahaq & 53 \\
\hline 27 & Vira Salsabila Syah Fitri & 71 & Zaetin Anggi Sasmita & 67 \\
\hline
\end{tabular}

After obtaining the pretest value of the students' ecological awareness, the next step is to do the Prerequisite test. The prerequisite test is carried out to determine the level of equality or similarity in the level of ecological awareness of students before receiving treatment, some of the Prerequisite test results are as follows:

1) Normality Test

Table 7. Affective Prerequisite Normality Test

\begin{tabular}{|c|c|c|c|c|c|c|}
\hline & $\begin{array}{l}\text { Kolmogoro } \\
\text { v-Smirnova }\end{array}$ & \multicolumn{5}{|c|}{ Shapiro-Wilk } \\
\hline & Statistics & df & Sig. & Statistics & df & Sig. \\
\hline
\end{tabular}




\begin{tabular}{|l|r|r|r|r|r|r|}
\hline Control Class Pretest & .129 & 27 & $.200 *$ & .930 & 27 & .071 \\
\hline $\begin{array}{l}\text { Pretest Experiment } \\
\text { Class }\end{array}$ & .140 & 27 & .184 & .953 & 27 & .251 \\
\hline
\end{tabular}

a. Lilliefors Significance Correction

* This is a lower bound of the true significance.

Based on the data above, it is known the significance normality shapiro-wilk for The pretest of the control and experimental classes were 0.071 and 0.251 , respectively. So that the normality value of shapiro-wilk $>0.05$, then disimshow that the pretest data is normally distributed.

2) Homogeneity Test

Table 8. Affective Inscription Homogeneity Test

Ecological

\begin{tabular}{|c|c|c|c|}
\hline $\begin{array}{l}\text { Levene } \\
\text { Statistics }\end{array}$ & dfl & $\mathrm{df} 2$ & Sig. \\
\hline 1,848 & 1 & 52 & .180 \\
\hline
\end{tabular}

Based on the data above, it is known the significance equal to $0.180>0.05$, then disimreturn that the control class and Experiments come from the same variant or are homogeneous.

3) Independent Sample t-test

Table 9. Independent Samples Affective Test

\begin{tabular}{|c|c|c|c|c|c|c|c|c|c|c|}
\hline & $\begin{array}{c}\text { Levene's } \\
\text { Test for } \\
\text { Equality of } \\
\text { Variances }\end{array}$ & \multicolumn{9}{|c|}{ t-test for Equality of Means } \\
\hline & \multirow[t]{2}{*}{$\mathrm{F}$} & \multirow[t]{2}{*}{ Sig. } & \multicolumn{2}{|c|}{$\mathrm{t}$} & \multirow[t]{2}{*}{ df } & \multirow[t]{2}{*}{$\begin{array}{c}\text { Sig. } \\
(2- \\
\text { tailed })\end{array}$} & \multirow[t]{2}{*}{$\begin{array}{l}\text { Mean } \\
\text { Differ } \\
\text { ence }\end{array}$} & \multirow[t]{2}{*}{\begin{tabular}{c|} 
Std. \\
Error \\
Differ \\
ence
\end{tabular}} & \multicolumn{2}{|c|}{$\begin{array}{c}95 \% \\
\text { Confidence } \\
\text { Interval of the } \\
\text { Difference }\end{array}$} \\
\hline & & & & & & & & & $\begin{array}{c}\text { Lowe } \\
\mathrm{r}\end{array}$ & Upper \\
\hline $\begin{array}{l}\text { Ecologica } \\
1 \\
\text { Intelligen }\end{array}$ & $\begin{array}{l}\text { Equal } \\
\text { variances } \\
\text { assumed }\end{array}$ & 1,848 & .180 & 382 & 52 & .704 & $-1,000$ & 2,617 & $-6,252$ & 4,252 \\
\hline $\begin{array}{l}\text { ce Pretest } \\
\text { Value }\end{array}$ & $\begin{array}{l}\text { Equal } \\
\text { variances } \\
\text { not } \\
\text { assumed }\end{array}$ & & & 382 & $\begin{array}{r}49,76 \\
0\end{array}$ & .704 & $-1,000$ & 2,617 & $-6,257$ & 4,257 \\
\hline
\end{tabular}

Based on the test The Independent Samples $t$ Test shows that the significance is $0.704>0.05$, so it can be concluded that the two classes have equality and there is no mean 
difference in terms of the level of ecological awareness. So that the two classes meet the requirements to be sampled. After the conditions have been statedfulfill then the test is carried out in the control class and experiment with the posttest results of ecological awareness as follows:

Table 10. Posttest Results Attitude of Ecological Awareness of Experiment and Control Class

\begin{tabular}{|c|l|c|l|c|}
\hline \multirow{2}{*}{$\begin{array}{c}\text { No } \\
\text {. Control Class }\end{array}$} & \multicolumn{1}{|c|}{ Name } & Postest & \multicolumn{1}{c|}{ Experiment Class } \\
\hline 1 & Abdul Wafi & 64 & Ade Maula Yahya & Postest \\
\hline 2 & Afif Aminudin & 72 & Ardian Farid & 80 \\
\hline 3 & Alifah Firdhausyah & 68 & Ariel Dwi Ramadhani & 67 \\
\hline 4 & Alziqhra January & 72 & Aulia Mutiara Arseti & 76 \\
\hline 5 & Amanda Putri Rizqiya & 64 & Choirun Nisa & 78 \\
\hline 6 & Andhika Cahya & 69 & Peaceful Kayla Rezka & 78 \\
\hline 7 & Andika Eka Pratama & 60 & Dinda Ayu Trihapsari & 73 \\
\hline 8 & Chelsea Widya Santoso & 69 & Hammam Sholihin & 70 \\
\hline 9 & Dailly Drasta House & 64 & Ilham Afbel Karaka & 76 \\
\hline 10 & Dannel Susriatmanto & 68 & Java Bagus Maylana & 64 \\
\hline 11 & Davit Mustika & 68 & Julinka Nareswari & 73 \\
\hline 12 & Devinta Aprillia & 71 & M. Zaidan Dzaki Kansa & 78 \\
\hline 13 & Elsa Eliyanti Hutabarat & 70 & Margareta Videllia Chika & 71 \\
\hline 14 & Fajri Andinikhlas & 70 & Monika Ulim & 62 \\
\hline 15 & Holizah & 69 & Muhammad Ilham Mufaddil & 73 \\
\hline 16 & Izaki Surya Abdullah & 69 & Muhammad Rafi & 70 \\
\hline 17 & Jaka Afriza Nurchosim & 60 & Niken Zhulia Ayu Astutik & 76 \\
\hline 18 & Kayana Amoretta & 65 & Pritia Dwi Yulianti & 76 \\
\hline 19 & Luthfiah Adelya & 73 & Purnomo Hadi Saputro & 72 \\
\hline 20 & Moh. Anwar Rudin & 62 & Radiq Bima Alditya & 67 \\
\hline 21 & Muhammad Ilham & 65 & Rahadian Rizqy Irawan & 80 \\
\hline 22 & Muhammad Rendy & 73 & Renovaldy Arya & 76 \\
\hline 23 & Muhammad Ridlo & 59 & Rifaul Ihsan & 74 \\
\hline 24 & Naufal Hisyam & 65 & Selvia Yulira Pratama & 76 \\
\hline 25 & Patricia Aurha De Priza & 73 & Sophie Nayla Fattima & 74 \\
\hline 26 & Sandrina Widyatma & 71 & Yuniar Andini Ainahaq & 72 \\
\hline 27 & Vira Salsabila Syah Fitri & 76 & Zaetin Anggi Sasmita & 80 \\
\hline
\end{tabular}

After getting the value of the attitude of ecological awareness, then the effectiveness test is carried out to analyze aIf the questionnaire is made effective in increasing students' ecological awareness attitudes, an independent sample $t$ test will be carried out on the posttets results of the control and experimental classes, with the following hypothesis:

H0: There is no mean difference between the control and experimental classes

H1: There is a mean difference between the control and experimental classes

Test Decision:

H0: accepted, if t count with a significance level (2-tailed) $>0.005$

H1: rejected, if t count with a significance level (2-tailed) $<0.005$ 
The test results are as follows:

1) Normality Test

Table 11. Affective Normality Test

\begin{tabular}{|c|c|c|c|c|c|c|}
\hline $\begin{array}{l}\text { Kolmogoro } \\
\text { v-Smirnova }\end{array}$ & \multicolumn{6}{|c|}{ Shapiro-Wilk } \\
\hline & Statistics & df & Sig. & Statistics & df & Sig. \\
\hline Posttest Control Class & .153 & 27 & .107 & .958 & 27 & .335 \\
\hline $\begin{array}{l}\text { Posttest Experiment } \\
\text { Class }\end{array}$ & .144 & 27 & .160 & .937 & 27 & .101 \\
\hline
\end{tabular}

a. Lilliefors Significance Correction

Based on the data above, it is known the significance normality shapiro-wilk for Posttest for the Control and Experimental Classes were 0.335 and 0.101 , respectively. So that the normality value of shapiro-wilk $>0.05$, then disimshow that the posttest data is normally distributed.

2) Homogeneity Test

Table 12. Affective Homogeneity Test

The Posttest Value of Ecological Awareness

\begin{tabular}{|c|c|c|c|}
\hline $\begin{array}{c}\text { Levene } \\
\text { Statistics }\end{array}$ & df1 & $\mathrm{df} 2$ & Sig. \\
\hline .193 & 1 & 52 & .662 \\
\hline
\end{tabular}

Based on the data above, it is known the significance equal to 0.662>0.05, then disimrestore that data Posttest control class and Experiments come from the same variant or are homogeneous.

3) Independent Sample t-test

The requirements for the $\mathrm{t}$ test have been statedfulfill the normality and homogeneity, then the independent sample t-test is then carried out with the results as follows:

Table 13. Independent Samples Affective Test

\begin{tabular}{|c|c|c|c|c|c|c|c|}
\hline $\begin{array}{l}\text { Levene's } \\
\text { Test for } \\
\text { Equality of } \\
\text { Variances }\end{array}$ & \multicolumn{7}{|c|}{ t-test for Equality of Means } \\
\hline $\mathrm{F}$ & Sig. & $\mathrm{t}$ & df & $\begin{array}{l}\text { Sig. } \\
(2- \\
\text { tailed })\end{array}$ & $\begin{array}{l}\text { Mean } \\
\text { Differ } \\
\text { ence }\end{array}$ & \begin{tabular}{|l|} 
Std. \\
Error \\
Diffe \\
rence \\
\end{tabular} & $\begin{array}{c}95 \% \\
\text { Confidence } \\
\text { Interval of the } \\
\text { Difference }\end{array}$ \\
\hline & & & & & & & \begin{tabular}{|l|l} 
Lower & Upper
\end{tabular} \\
\hline
\end{tabular}




\begin{tabular}{|c|c|c|c|c|c|c|c|c|c|c|}
\hline $\begin{array}{l}\text { The } \\
\text { Posttest } \\
\text { Value of }\end{array}$ & $\begin{array}{l}\text { Equal } \\
\text { variances } \\
\text { assumed }\end{array}$ & 193 & .662 & $\begin{array}{r}4,33 \\
9 \\
\end{array}$ & 52 & .000 & $-5,481$ & $\begin{array}{r}1,26 \\
3\end{array}$ & $-8,017$ & $-2,946$ \\
\hline $\begin{array}{l}\text { Ecologica } \\
1 \\
\text { Intelligen } \\
\text { ce }\end{array}$ & $\begin{array}{l}\text { Equal } \\
\text { variances } \\
\text { not } \\
\text { assumed }\end{array}$ & & & $\begin{array}{r}4,33 \\
9\end{array}$ & $\begin{array}{r}51,98 \\
8\end{array}$ & .000 & $-5,481$ & $\begin{array}{r}1,26 \\
3\end{array}$ & $-8,017$ & $-2,946$ \\
\hline
\end{tabular}

Based on the test Independent Samples $t$ Test, it is known that the significance is $0.000<0.05$, it can be concluded that $\mathrm{H} 0$ is rejected and $\mathrm{H} 1$ is accepted that There is a mean difference between the control and experimental classes. So that dapat disimreport that the questionnaire developed was effective in increasing students' ecological awareness.

\section{Conclusion}

Based on the results of the above research, it can be concluded that the development of a questionnaire to measure the level of students' ecological awareness is proven effective because the measurement is not only based on one aspect, namely the attitude aspect, but is based on measuring three aspects, namely knowledge, attitudes and skills. Giving questionnaire tests to students who were given twice before and after learning about the history of oil in Cepu, the impact of oil refineries and ecological awareness proved to be significant and effective in measuring the ecological awareness of students of SMK Migas Cepu. However, this research is limited to students who are majoring in petroleum because it provides knowledge and attitudes for petroleum students who will later work in the world of petroleum, so that the analysis of students' ecological awareness needs to be further developed.

\section{References}

Abidin, N. F. (2020). Pembelajaran Sejarah Lokal di Sekolah. 3(1), 88-99.

Basirizadeh, F. S., et. al. (2020). A Study of Wuthering Heights from the Perspective of Eco-Criticism. Budapest International Research and Critics in Linguistics and Education (BirLE) Journal Vol 3 (4): 1623-1633.

Bruyere, B. L. (2008). The effect of environmental education on the ecological literacy of first-year college students. Journal of Natural Resources and Life Sciences Education, 37(1), 20-26.

Cepu, smk migas. (n.d.). Selamat Datang di SMK Migas Cepu.

Keraf, S. (2013). Fritjof Capra Tentang Melek Ekologi. https://jo(11), 54-81.

Landriany, E. (2014). Implementasi kebijakan adiwiyata dalam upaya mewujudkan pendidikan lingkungan hidup di SMA Kota Malang. Jurnal Kebijakan Dan Pengembangan Pendidikan, 2(1).

Lualhati, G. P., Catibog, F. J. A., Holgado, R. A. L., \& Liwanag, J. M. A. (2018a). Discovering Ecological Awareness of Filipino Education Students. International Journal of Applied Science, 1(2), p37. https://doi.org/10.30560/ijas.v1 n2p37

Lualhati, G. P., Catibog, F. J. A., Holgado, R. A. L., \& Liwanag, J. M. A. (2018b). Discovering Ecological Awareness of Filipino Education Students. International Journal of Applied Science, 1(2), p37-p37. 
Mccabe, R. G. (1931). Petroleum Refineris.pdf. Washington.

Mcginn, A. E. (2014). Quantifying and Understanding Ecological Literacy: A Study of First Year Students at Liberal Arts Institutions. Retrieved from http://scholar.dickinson.edu/student_honors

Prastiwi, L., Sigit, D. V., \& Ristanto, R. H. (2019). Relationship Between Academic Ability and Environmental Problem-Solving Skill: A Case Study at Adiwiyata Schools in Tangerang City, Indonesia. Üniversitepark Bülten, 8(1), 76.

Pytel, K., Piaskowska, M., \& Migo, P. (2016). Teaching bioscience in primary and middle school and children's ecological awareness. Proceedings of the International Scientific Conference. Volume II, 298, 308.

Rosmiati, Wahyuni, A., and Syarifuddin, A. (2020). Ombilin Coal Mine Site: History and Potential as a Learning Source for the History of the Economy Based on Outdoor Learning. Budapest International Research and Critics in Linguistics and Education (BirLE) Journal Vol 3 (3): 1343-1352.

Siti Nur Fatimah, Wasino, B. (2016). Nasionalisasi Tambang Minyak di Cepu dan Pengelolaannya Tahun 1950-1966. Journal of Indonesian History, 5(1), 52-61.

Sulistyono, S., Suntoro, S., \& Masykuri, M. (2011). Kajian dampak tumpahan minyak dari kegiatan operasi kilang minyak terhadap kualitas air dan tanah (Studi Kasus Kilang Minyak Pusdiklat Migas Cepu). Jurnal Ekosains, 4(2), 23-34. Retrieved from http://jurnal.pasca.uns.ac.id/index.php/ekosains/article/view/267/252

Suwandi, S., \& Yunus, A. (2016). Kecerdasan Ekologis dalam Buku Sekolah Elektronik Mata Pelajaran Bahasa Indonesia SMP. Litera, 15(1).

Yin, R. K. (2017). Designing Case Studies. In Case Study Research and Applications: Design and Methods. 